\title{
A Method for Assessing the Relationship Between Cropload and Crop Value Following Fruit Thinning
}

\author{
Ed Stover ${ }^{1}$ and Ferdinand Wirth ${ }^{2}$ \\ University of Florida, Indian River Research and Education Center, 2199 \\ South Rock Road, Ft. Pierce, FL 34945-3138
}

\section{Terence Robinson}

Department of Horticultural Sciences, New York State Agricultural Experiment Station, Cornell University, Geneva, NY 14456-0462

Additional index words. apple, citrus, Malus Xdomestica, Citrus reticulata, NAA, naphthalene acetic acid, BA, 6-benzyladenine

\begin{abstract}
Analysis of apple (Malus $\times$ domestica Borkh.) and citrus thinning experiments indicates that the relationships between cropload, fruit size, and total yield can be used to assess optimal cropload for highest crop value. Mean fruit size increased and total yield declined as the cropload (number of fruit/ $\mathrm{cm}^{2}$ trunk cross-sectional area) was reduced through the use of chemical thinners. Because crop value is influenced by fruit size and total yield, intermediate croploads gave the highest economic returns in all experiments evaluated. For 'Empire' apple, croploads greater than those expected to provide good return bloom often produced the highest crop value for a single year. In citrus, optimal crop values resulted from a broad range of intermediate croploads. A method is described to analyze optimum cropload from thinning experiments.
\end{abstract}

Thinning is a critical factor in the profitability of commercial production of apple (e.g., Forshey, 1986), peach [Prunus persica (L.) Batsch.] (Southwick et al., 1995), and pear (Pyrus communis L.) ( Stover et al., 1995), and has also been demonstrated to have economic potential in the production of citrus (Wheaton and Stewart, 1973). Some fruit cultivars develop a strong pattern of biennial bearing if the number of fruit per tree is not reduced during early fruit development in a year of heavy cropping (reviewed by Monselise and Goldschmidt, 1982). Without thinning, alternating between excessive crops of very small fruit and light crops of large fruit often reduces overall production, results in excessive growth in light-cropping years, and can cause substantial limb breakage from heavy crops. In addition to obvious benefits from simply reducing biennial bearing, the much higher value of large fruit provides substantial incentive for reducing croploads to levels yielding a high proportion of such fruit. For many apple cultivars (Table 1), the packinghouse price of extra-fancy 100-count fruit (number of fruit required to fill an 18.2-kg carton, mean weight $180 \mathrm{~g}$ ) is almost twice as great as that of 160count fruit (typically sold in $1.36-\mathrm{kg}$ bags, mean weight $114 \mathrm{~g}$ ). Similar price differen-

Received for publication 3 Jan. 2000. Accepted for publication 12 May 2000. Florida Agricultural Experiment Station Journal Series No. R-07284 The cost of publishing this paper was defrayed in part by the payment of page charges. Under postal regulations, this paper therefore must be hereby marked advertisement solely to indicate this fact.

${ }^{1}$ Dept. of Horticultural Sciences. E-mail address: ews@gnv.ifas.ufl.edu

${ }^{2}$ Food and Resource Economics Dept. tials are observed for fresh citrus fruit (Table 2 ), as well as for peaches and pears (data not shown). Unfortunately, in many cases, reducing cropload not only increases fruit size but also reduces the overall yield/ha and crop value is determined by the combination of return per carton and the number of packed cartons/ha.

While growers have a sense as to what croploads provide high crop value, there has been little systematic attempt to evaluate the economics of thinning so that growers can target levels providing optimal crop value, or assess differences in thinning strategies. Most thinning studies evaluate the effect of thinning on fruit size and yield but no effort is made to convert those two counterbalancing effects into economic results. Most economic interpretations of thinning have simply compared results from individual thinning treatments (e.g., Cook, 1985; Silsby et al., 1991) rather than assessing the relationship between value and degree of thinning. Bergh (1990) reported on the use of regression techniques to evaluate the contribution of cropload, fruit size, and other parameters to final crop value, and concluded that cropload (number of fruit/ $\mathrm{cm}$ trunk circumference) is the dominant variable. In this paper, we report a method for evaluating the response curve of farm-gate crop value vs. cropload to provide a better basis for evaluating and optimizing economic response to thinning. Initial efforts were directed toward apple, where thinning is routinely utilized, and the method was then used to assess response to thinning in citrus, where thinning is not a frequent practice.

\section{Materials and Methods}

Thinning experiments. Apple thinning trials were conducted from 1994-97 in commercial

Table 1. Fruit and carton sizes and average packinghouse prices for 1995-96 for three apple cultivars in Eastern New York.

\begin{tabular}{|c|c|c|c|c|}
\hline \multirow{2}{*}{$\begin{array}{l}\text { Fruit and } \\
\text { carton sizes }\end{array}$} & \multirow{2}{*}{$\begin{array}{c}\text { Wt/box } \\
(\mathrm{kg})\end{array}$} & \multicolumn{2}{|c|}{ Fruit size (g) } & \multirow{2}{*}{$\begin{array}{c}\text { Value for extra- } \\
\text { fancy grade (\$/box) }\end{array}$} \\
\hline & & Maximum & Mean & \\
\hline \multicolumn{5}{|c|}{ McIntosh } \\
\hline$<5.72 \mathrm{~cm}$ diam. & --- & 73 & --- & --- \\
\hline$\geq 5.72 \mathrm{~cm}$ diam. & 17.7 & 104 & 88 & 7.50 \\
\hline$\geq 6.35 \mathrm{~cm}$ diam. & 17.7 & 115 & 109 & 8.75 \\
\hline \multicolumn{5}{|c|}{ "P" box } \\
\hline 120 fruit & 16.2 & 148 & 132 & 10.00 \\
\hline 100 fruit & 16.2 & 181 & 165 & 16.00 \\
\hline \multicolumn{5}{|c|}{ “F” box } \\
\hline 100 fruit & 17.8 & 204 & 193 & 16.00 \\
\hline 80 fruit & 17.8 & none & --- & 16.00 \\
\hline \multicolumn{5}{|c|}{ Empire } \\
\hline$<5.72 \mathrm{~cm}$ diam. & --- & 74 & --- & --- \\
\hline$\geq 5.72 \mathrm{~cm}$ diam. & 17.7 & 111 & 92 & 7.00 \\
\hline$\geq 6.35 \mathrm{~cm}$ diam. & 17.7 & 130 & 120 & 8.50 \\
\hline \multicolumn{5}{|c|}{ "P" box } \\
\hline 120 fruit & 16.6 & 147 & 139 & 10.00 \\
\hline 100 fruit & 16.6 & 187 & 167 & 15.50 \\
\hline \multicolumn{5}{|c|}{ "F" box } \\
\hline 100 fruit & 18.2 & 224 & 205 & 15.50 \\
\hline 80 fruit & 18.2 & none & --- & 15.50 \\
\hline \multicolumn{5}{|c|}{ Delicious } \\
\hline$<5.72 \mathrm{~cm}$ diam. & --- & 79 & --- & --- \\
\hline$\geq 5.72 \mathrm{~cm}$ diam. & 17.7 & 113 & 96 & 7.50 \\
\hline$\geq 6.35 \mathrm{~cm}$ diam. & 17.7 & 139 & 126 & 9.50 \\
\hline \multicolumn{5}{|c|}{ Fruit/box } \\
\hline $113-125$ & 18.6 & 176 & 158 & 10.00 \\
\hline $80-100$ & 18.6 & 250 & 213 & 11.00 \\
\hline $48-72$ & 18.6 & none & --- & 10.50 \\
\hline
\end{tabular}


Table 2. Size classes and midseason carton $(21.6 \mathrm{~kg})$ prices for two Florida tangerine cultivars in 1995-96 (Citrus Administrative Committee, 1996).

\begin{tabular}{|c|c|c|c|}
\hline \multirow{2}{*}{$\begin{array}{l}\text { Fruit per } \\
\text { carton }\end{array}$} & \multicolumn{2}{|c|}{ Fruit size $(\mathrm{g})$} & \multirow{2}{*}{$\begin{array}{l}\text { Value per } \\
\text { carton }(\$)\end{array}$} \\
\hline & Minimum & Mean & \\
\hline \multicolumn{4}{|c|}{ Dancy } \\
\hline 210 & 92 & 103 & 7.91 \\
\hline 176 & 110 & 122 & 8.93 \\
\hline 150 & 129 & 144 & 10.61 \\
\hline 120 & 160 & 180 & 12.42 \\
\hline 100 & 200 & 216 & 13.96 \\
\hline 80 & 240 & 270 & 15.33 \\
\hline \multicolumn{4}{|c|}{ Honey (or Murcott) } \\
\hline 176 & 110 & 122 & 11.78 \\
\hline 150 & 129 & 144 & 12.59 \\
\hline 120 & 160 & 180 & 13.30 \\
\hline 100 & 200 & 216 & 14.53 \\
\hline 80 & 240 & 270 & 16.39 \\
\hline
\end{tabular}

orchards in eastern New York State. Orchard blocks were on silt loam soils typical of commercial production in the region, with productive and uniform trees. For experiments discussed in detail, age, scion variety, and rootstock are listed in Table 3. The 'Delicious' trees were on Stark three-piece rootstocks, which have two interstems. During the early 1980 s, these rootstocks were typically seedling root/K-14 Crab interstem/Clark 6 interstem, but, sometimes 'Wayne' was used as the middle genotype and Clark 52 was used rather than Clark 6 (Elmer Kidd, personal communication), and it is uncertain precisely what configuration was used in the experimental orchard. Numbers of blossom clusters were counted on either entire trees or on three representative branches per tree. Trunk circumference was measured $25 \mathrm{~cm}$ above the soil level, and where branch counts were employed, the circumference of branches used was also determined. Trees were blocked by number of blossom clusters per $\mathrm{cm}^{2}$ trunk cross-sectional area (TCSA) or number of blossom clusters per $\mathrm{cm}^{2}$ branch cross-sectional area.

The citrus data analyzed were from a trial conducted in 1968 by Dr. Adair Wheaton of the Citrus Research and Education Center in central Florida (Wheaton, personal communication ). A grove with productive and uniform trees of 'Dancy' tangerine (Citrus reticulata Blanco) on rough lemon rootstock (Citrus limon L.) on deep sand soil near Lake Alfred, Fla. was selected and treatments were assigned according to a randomized completeblock design with location in the grove used as the blocking factor.

In each experiment, each treatment was applied to five to eight individual trees. Chemical thinners were applied using either a high-pressure hand gun to runoff or commercial air-blast speed sprayers with water volumes at full tree-row volume (TRV), dilute (Wilcox et al., 1995). Naphthalene acetic acid (NAA) was used in the formulation of Fruitone-N ${ }^{\circledR}$ or Fruit Fix K-Salt ${ }^{\circledR} 200$ (AmVac Chemicals, Los Angeles) for apples, while a product similar to Fruit Fix containing the potassium or ammonium salt of NAA was used for the citrus thinning studies in 1968. 6-Benzyladenine (BA) was used in the

Table 3. Scion cultivars, rootstock, and planting year of apple trees used in experiments discussed in detail. All experiments were conducted in Clintondale, N.Y., in 1995.

\begin{tabular}{lcc}
\hline \hline Scion cultivar & Rootstock & Year planted \\
\hline Empire & M.7a & 1989 \\
Marshall McIntosh & M.7a & 1989 \\
Starkrimson Delicious & Stark three-piece rootstock & 1981 \\
\hline${ }^{2}$ Usually seedling root/K-14 Crab interstem/Clark 6. &
\end{tabular}

product Accel ${ }^{\circledR}$ (AbbottLaboratories, Chicago), and carbaryl (1-naphthyl-N-methylcarbamate) in the Sevin $\mathrm{XLR}+{ }^{\circledR}$ formulation (RhonePoulenc, Research Triangle Park, N.C.). Applications to apple were made at a range of phenological stages from petal fall to $15 \mathrm{~mm}$ king fruitlet diameter (KFD) as indicated. Application in citrus occurred during the period of physiological drop in mid-May.

At commercial harvest, all of the fruit were harvested from the treated trees and data were collected on the total number and the total weight of fruit/tree. For apple, numbers of dropped fruits were counted and assumed to be of average fruit weight. From these data, the mean fruit size and number of fruit $/ \mathrm{cm}^{2}$ TCSA was determined for each tree.

A random sample of 20-25 fruit was also collected from each tree. The sample fruit were weighed and the standard deviation calculated.

Regressions between fruit size and cropload. Linear regressions relating fruit size to fruit $/ \mathrm{cm}^{2}$ TCSA or fruit/tree were determined for individual thinning experiments based on the means for nonthinned controls and either means from all thinning treatments or groups of related thinning treatments, using Proc RSREG (SAS Institute, Cary, N.C.). The regression equations were used to predict mean fruit size at a range of croploads represented within each experiment, so that the underlying relationship between cropload and both fruit size and crop value could be evaluated, rather than comparing only results of individual treatments.

Estimating fruit size distribution. Since fruit size distribution within a tree is typically normal (data not shown), standard deviations for mean fruit size from each experiment were used to estimate the percentage of total crop in each size class. This was done for a range of croploads for each experiment. Economic size classes were derived using weight settings typical of commercial packing lines. The $\mathrm{Z}$ statistic [(maximum and minimum size for adjacent economic size classes-mean fruit size for cropload)/standard deviation] was calculated for each breakpoint between size classes. Using Proc RSREG (SAS Institute), an equation approximating percentage from the $\mathrm{Z}$ statistic was derived. Percentage of the total crop in each size class was approximated by subtracting the percentage of fruit below the minimum size threshold from the percentage below the maximum size threshold.

Estimatingfarm-gate crop value. The value of fruit in each economic size class was calculated using commercial prices. Packinghouse prices for apple were obtained from a group of industry leaders in eastern New York State
(Table 1) and from published data (Citrus Administrative Committee, 1996) for citrus (Table 2). Costs for each step from harvesting fruit through transport, storage, packing, and final sales commission were obtained from a group of industry leaders in eastern New York State for the apple data (Table 4) and from published data (Muraro and Hebb, 1996) for citrus (Table 5). These costs were subtracted from the prices received at the packinghouse to generate the potential return to the grower per carton of fruit, when fruit size was the only criterion affecting grade. By multiplying appropriate parameters [e.g., (mean g/fruit) $\times$ (number of cartons $/ \mathrm{g}$ fruit $) \times\left(\right.$ fruit/TCSA cm$\left.{ }^{2}\right)$ (mean TCSA $\mathrm{cm}^{2} /$ tree) $\times$ (numbers of trees/ ha) $\times$ (proportion of total yield in indicated size class $) \times($ dollar return to grower/carton in indicated size class)], and summing over all size classes, the potential dollar return/ha was generated for each cropload.

Evaluating optimal targets for cropload adjustment. For apples, cropload was plotted against mean fruit size, bushels $(=19.1 \mathrm{~kg}) / \mathrm{ha}$, bushels of 100-count fruit/ha, and potential dollar return/ha. Resultant curves were used to assess croploads providing maximum potential return/ha from thinning.

For citrus, cropload in fruit/tree was plotted against mean fruit size, cartons/ha, and potential dollar return/ha. Resultant curves were used to assess croploads providing maximum potential return/ha from thinning.

\section{Results}

Regressions between fruit size and cropload. When treatment means from 19 apple thinning experiments were used in linear regressions of mean fruit size on fruit $/ \mathrm{cm}^{2}$ TCSA, the resultant $r^{2}$ values ranged from 0.550 to 0.993 with a mean value of 0.788 . Analysis of treatment means from the one citrus thinning experiment provided a linear regression between fruit/tree and mean fruit size with resultant $r^{2}$ of 0.903 . As expected, virtually identical results were obtained when regressions were run with SAS Proc RSREG or with Analysis Tools under the Tools menu of Microsoft Excel ${ }^{\circledR}$ (Redmond, Wash.) (data not shown).

Estimating fruit size distribution. Standard deviations for fruit size were evaluated for treatments in each experiment, and in some cases, were significantly different by analysis of variance (ANOVA) (data not shown). When there was no cropload effect on standard deviation, the mean standard deviation for fruit size in each experiment was used to estimate fruit size distribution. If standard deviations were statistically different for different size 
Table 4. Estimated costs (U.S. \$) per 18.2-kg box for apple harvest, handling, storage, packing, and sales (1995-96).

\begin{tabular}{lc}
\hline \hline Harvesting labor and transport to storage & 1.25 \\
Postharvest drenching & 0.17 \\
Cold storage, regular & 0.80 \\
Cold storage, controlled atmosphere (CA) & 1.50 \\
Average storage (10\% no storage, 30\% regular storage, 60\% CA) & 1.14 \\
Packing for sale in bags & 3.75 \\
Packing for sale in cells (used in 'McIntosh') & 4.25 \\
Packing for sale in trays (used in 'Empire' and 'Delicious') & 4.05 \\
Running culls over packing line & 1.40 \\
Apple marketing order tax & 0.17 \\
Sales commission (8.75\% of FOB price) & \\
\hline
\end{tabular}

Table 5. Published costs (U.S. \$) per carton (21.6 $\mathrm{kg}$ ) for picking, roadsiding, hauling, and packing of Florida tangerines (Muraro, 1995).

\begin{tabular}{ll}
\hline \hline Picking & 0.786 \\
Roadsiding & 0.500 \\
Hauling & 0.214 \\
DOC tax & 0.175 \\
Cooling & 0.117 \\
Labeling & 0.133 \\
Packing (total) & 4.031 \\
Elimination charge & 0.350 \\
Hauling eliminations & 0.170 \\
Sales commission & $(7.5 \%$ of FOB price)
\end{tabular}

classes, a regression of standard deviation against fruit size was used to generate a standard deviation for each size class. However, use of a mean standard deviation did not markedly alter the resultant relationship between cropload and fruit value (data not shown).

To facilitate rapid analysis of data with a spreadsheet, an equation estimating percentage of total crop below each pivotal fruit size was developed through regression against tabulated probabilities for the $\mathrm{Z}$ statistic. For $\mathrm{Z}<0$, percentage of total crop below the indicated fruit size $=(50.237537)+(42.3442892 \mathrm{Z})+$ $\left(9.100796 Z^{2}\right)$; for $Z>0$, percentage of total crop below the indicated fruit size $=(100)-$ $(50.237537)+(42.3442892 \mathrm{Z})-(9.100796$ $\left.Z^{2}\right)$. For $Z>2.3$ or $<-2.3$, percentage of total crop below indicated fruit size was designated as $100 \%$ and $0 \%$, respectively. These equations and substitutions were used with relevant if/then statements for $\mathrm{Z}<0, \mathrm{Z}>0, \mathrm{Z}>2.3$, and $\mathrm{Z}<-2.3$. The $r^{2}$ for this approximation vs. tabular $\mathrm{Z}$ value probabilities was 0.999 . Estimated percentage of total crop below indicated fruit size from this regression equation resulted in deviations from the values given for $\mathrm{Z}$ in a normal probability table of no more than $1.2 \%$ of the total crop for any $Z$ value (Fig. 1). For $Z$ values from -2.7 to 2.7 , the deviation from the percentage estimated by this equation and calculated from a normal probability table averaged only $0.51 \%$ of the total crop.

Apple assessment using 1996 economic factors. Use of 1996 prices per carton and variable costs in this method of analysis resulted in a characteristic response curve of potential farm-gate crop value vs. cropload (Fig. 2). In all orchards and groves evaluated, the potential farm-gate crop value, with all postharvest variable costs subtracted, increased as cropload was reduced, reached a maximum value and then declined as cropload was reduced further.

For 'Empire' (Fig. 2), maximum potential dollar return/ha often occurred at very high croploads, around nine fruit $/ \mathrm{cm}^{2}$ TCSA. The cropload providing maximum dollar return/ ha tended to decrease with orchard age in our small sample (data not shown), possibly because containment pruning resulted in higher TCSA for similar canopy volumes. In all cases, the economic maximum was achieved near the point of maximum production of 100-count fruit/ha. Although average fruit size increased as cropload was reduced further, the number of cartons of 100-count fruit/ha remained stable or declined slightly

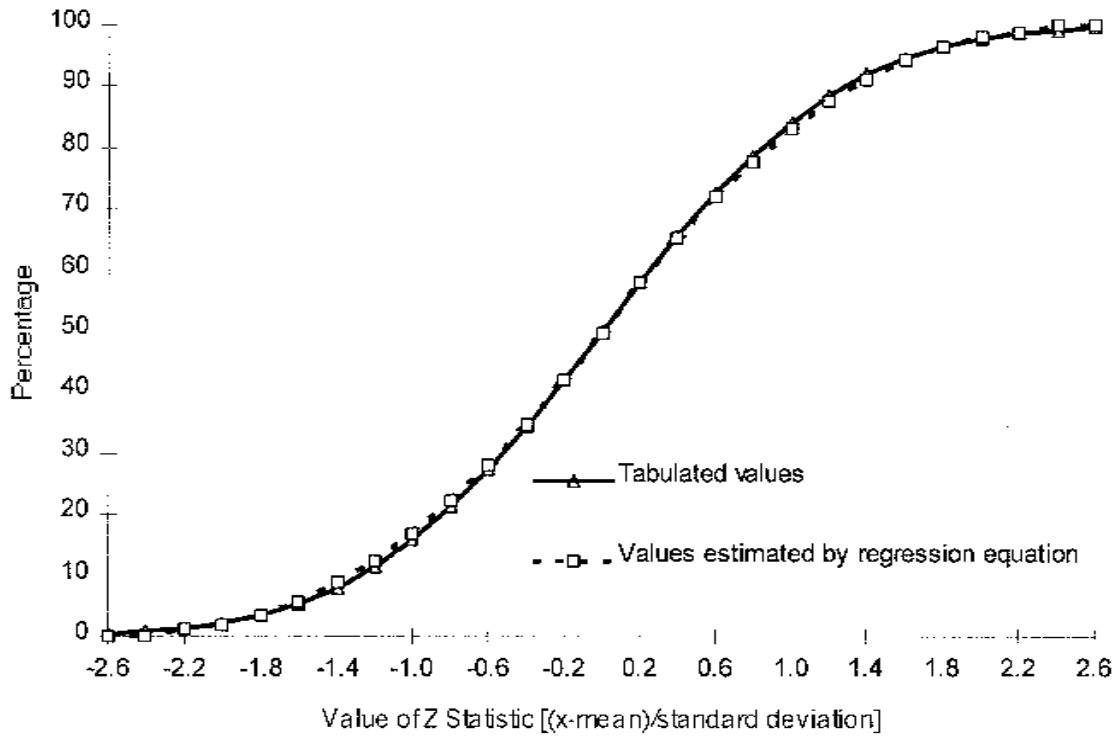

Fig. 1. Comparison of tabulated values for $\mathrm{Z}$ and approximation using regression equation.
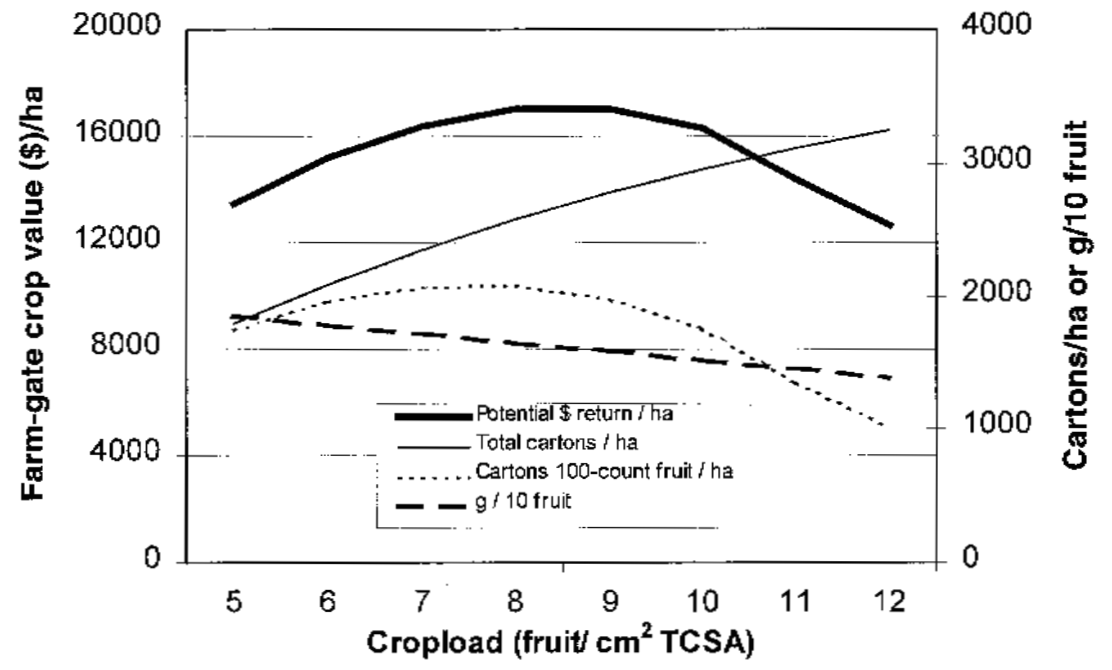

Fig. 2. Effect of cropload on potential return/ha from use of Accel ${ }^{\circledR}$ to thin seventh leaf 'Empire'/M.7a apple at Clintondale, N.Y., 1995, based on 1995-96 costs and FOB prices.

while cartons/ha of smaller fruit sizes declined sharply.

For one 'Empire' data set, there were numerous thinning treatments where NAA or $\mathrm{BA}$ alone at several concentrations, or the same materials plus carbaryl, were applied at $10 \mathrm{~mm}$ KFD to generate a range of croploads. By extracting data from each type of thinning treatment (NAA vs. BA) and analyzing them separately by the described method, one can assess the effect of NAA vs. BA on the overall response curve of grower return vs. cropload. In this experiment, use of BA enhanced fruit size at most croploads but did not change the cropload at which economic return was maximized (Fig. 3).

For 'McIntosh' (Fig. 4A) about half of the orchards produced the maximum potential 


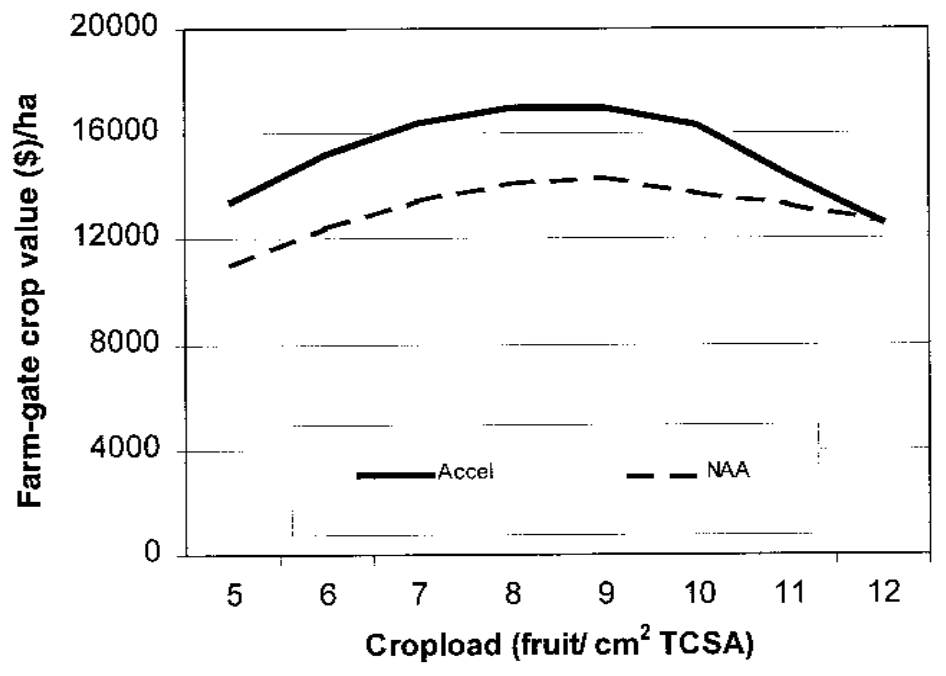

Fig. 3. Effects of thinning with Accel ${ }^{\circledR}$ vs. NAA at $10 \mathrm{~mm}$ king fruitlet diameter on potential return/ha on seventh leaf 'Empire'/M.7a apple at Clintondale, N.Y., 1995, based on 1995-96 costs and FOB prices.
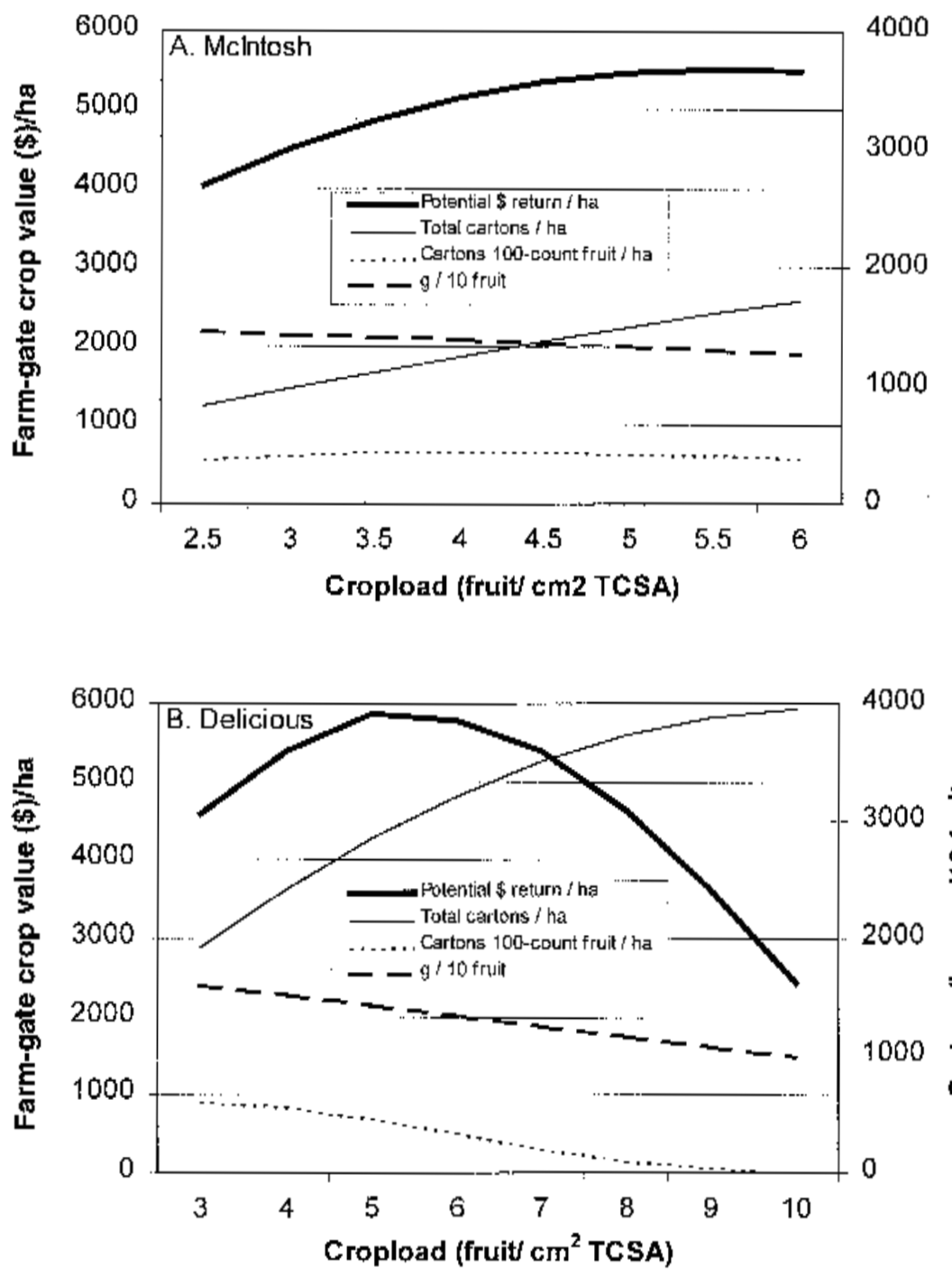

Fig. 4. Effect of cropload on potential return/ha from use of NAA to thin (A) seventh leaf 'Marshall McIntosh'/M.7a apple, and (B) 15th leaf 'Starkrimson Delicious'/Stark three-piece rootstock (usually seedling root/K-14 Crab interstem/Clark 6 interstem) apple at Clintondale, N.Y., 1995, based on 199596 costs and FOB prices. dollar return/ha with little or no cropload reduction. The remaining blocks displayed a pattern similar to that observed in 'Empire', as did 'Red Delicious' (Fig. 4B).

Tangerine assessment using 1996 economic factors. The response curve of 'Dancy' tangerine crop value vs. cropload was similar to those observed in apple (Fig. 5), with maximum crop value varying little over a broad range of croploads where the likelihood of adequate return bloom is high.

\section{Discussion}

Regressions between fruit size and cropload. The high correlation coefficients between cropload and fruit size support use of response curves from these regression equations to examine underlying relationships. By extension, the high $r^{2}$ values and the major importance of fruit size in crop value support the use of these equations in evaluating the economic significance of cropload adjustment. Bergh (1990) reported that cropload was the single factor most important in comparing crop value from year to year. In some apple growing regions, less enhancement in fruit size is apparent from reducing cropload (Ross Byers, personal communication), suggesting that resources may be partitioned into vegetative growth instead.

Estimating fruit size distribution. Use of the equation approximating the percentage of fruit at various values for the $\mathrm{Z}$ statistic permits use of typical spreadsheet programs. Slightly greater accuracy can be attained using statistical programs that generate areas for $Z$ values, but the errors are quite small when the described approximation is used. Much faster evaluation using this approximation and opportunity for widespread application are major advantages. Error in economic analysis from using this approximation will become greater in situations where the value of product at either or both extremes of the normal distribution is much greater than the mean value. The approximation underestimates the proportion of the crop falling into the most infrequent size classes (Fig. 1).

Estimating farm-gate crop value. Plotting the response curves of variables such as total yield, fruit size, or yield of highest value sizes vs. cropload provides insights into optimizing control of cropping for maximum crop value. All of our analyses produced a characteristically shaped response curve for potential farmgate crop value vs. cropload (Fig. 2). Bergh (1990) reported similar curves for value/ha and $\mathrm{t} \cdot \mathrm{ha}^{-1}$ in South Africa. While our analyses consider only the effect of fruit size on grade, the effect of cropload in apple is unlikely to significantly influence grade based upon any other factors except color development. Routine use of multiple pickings to harvest fruit at adequate color will probably reduce the effect of cropload on color development. For operations where percentage of packout is well below $100 \%$, insertion of a cullage factor would project crop value for varying levels of cullage. Costs of thinning treatments also should be included in assessments. 


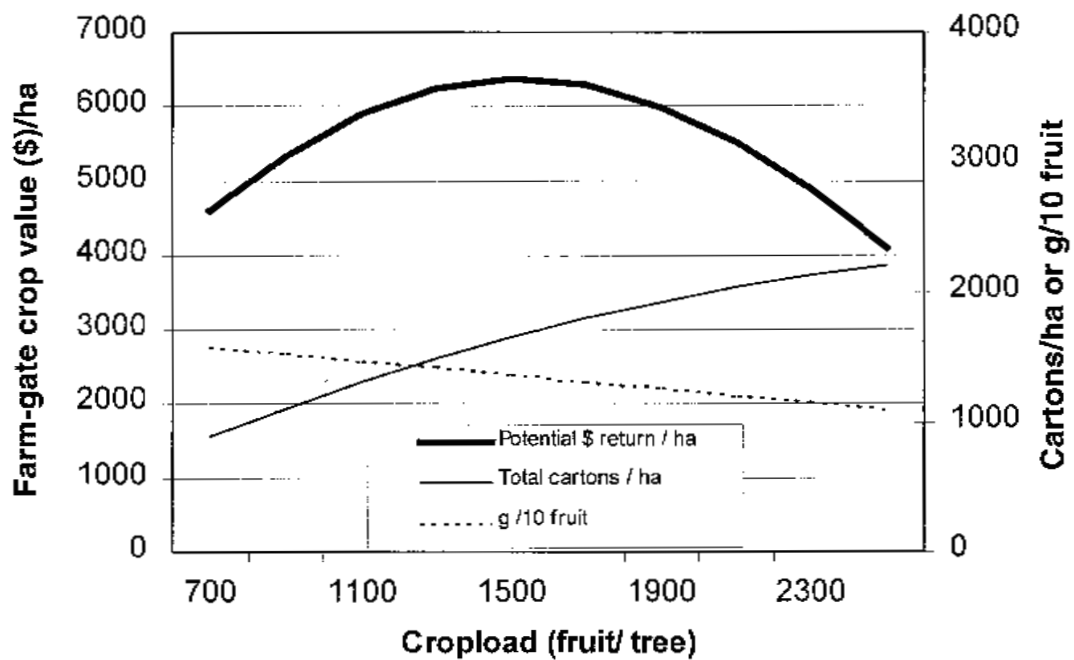

Fig. 5. Effect of cropload on potential return/ha, extrapolated from 1968 'Dancy' thinning data and 1996 costs and FOB prices.

Economics of cropload in apple. For 'Empire' in New York State using 1996 economic factors (Fig. 2), maximum potential crop value/ha in our trials often occurred at croploads greater than those likely to ensure good return bloom (Warren Stiles, personal communication). In this cultivar, growers would typically attain greatest return by adjusting cropping to levels that approach the maximum capable of sustaining return bloom Unfortunately, maximum sustainable cropload that consistently provides good return bloom is little understood. Almost certainly this value will vary with scion cultivar, rootstock, degree of stress (water and pest pressure), orchard age, certain growth regulator treatments, and probably both meso-climactic and annual environmental factors.

The steep decline in orchard crop value as cropload falls below that yielding maximum return provides a strong argument for developing thinning strategies to optimize croploads. Currently, most commercial growers in New York State apply a chemical thinner only once on most orchard blocks, with some handthinning later in the season when there is little influence on fruit size (Goffinet et al., 1995) or return bloom (Williams and Edgerton, 1981). A single thinning opportunity and the need for good return bloom force many growers to risk overthinning rather than compromise the subsequent season's crop. In our analyses with 'Empire' apple, the loss in potential crop value in many blocks is estimated at $\$ 400-800 /$ ha as croploads are reduced from seven to five fruit/ $\mathrm{cm}^{2}$ TCSA. We hypothesize that orchard profitability can be significantly enhanced through: 1) identification of target croploads for optimal crop value both within a growing season and for good return bloom; and 2) development of multiple thinning programs in which each subsequent treatment is based on monitoring the effect of earlier treatments to approach target croploads.
Virtually any thinning reduced profitabilwe studied, most of which were the 'Marshall' strain. In many 'McIntosh' blocks it is probably wise to use carbaryl alone, a low rate of NAA, or Accel ${ }^{\circledR}$ alone to break up clusters of fruit/spur and enhance color development.

Economics of cropload in citrus. Analysis of data from chemical thinning of 'Dancy' tangerine in Florida displayed a pattern similar to that observed in apple (Fig. 5), supporting the economic benefit of developing recommendations for routine thinning of tangerines. 'Dancy' and several other tangerine cultivars display severe alternate bearing (Monselise and Goldschmidt, 1982; Wheaton, 1997). Since chemical thinning is virtually unused in Florida citrus (Davies, 1984), many growers now alternate between large crops of small fruit and small crops of large fruit, both providing returns well below the range of optimal crop value (Fig. 5). The broad, fairly flat curve in the range of maximum crop value suggests that the citrus grower has a fairly wide window of acceptable croploads. Similar analyses conducted on cropload vs. fruit size data from a grapefruit (Citrus $X$. paradisi Macfad.) trial (data not shown) indicate that control of cropping is likely to be remunerative in this commodity as well. Crop control studies have been initiated in a range of citrus cultivars.

Utility of this method. The method of analysis described is easily conducted using a spreadsheet on a personal computer. After setting up the analysis, one can easily alter economic values or insert different data sets, permitting ready analysis of data, including cropping and complementary economic parameters in any commodity, or comparing different types of treatments. Regressions, focusing on the fundamental relationships between cropload and resultant yield and fruit size distribution, simplify analysis and ity in many 'McIntosh' blocks (Fig. 4A) that assist understanding of important consequences of controlling cropload.

Use of this method of analyzing thinning experiments will allow the integration of the counterbalancing effects of increasing fruit size while reducing yield into one economic variable. Most thinning experiments are of limited utility to growers since they concentrate on fruit size without considering the cost in yield and the overall economic impact of achieving that increased fruit size. When appropriate economic factors are incorporated into the analysis, this method provides graphical demonstration of the relationship between cropload and crop value, provides an estimate of optimal cropload, and suggests the relative risks of achieving croploads both above and below those providing greatest crop value.

\section{Literature Cited}

Bergh, O. 1990. Proposed regression model for calculating optimum crop levels of apple trees. S. Afr. J. Plant Soil 7:19-25.

Citrus Administrative Committee. 1996. Annual statistical report, 1995-96 season. Lakeland, Fla.

Cook, R.L. 1985. Does supplemental hand thinning pay? Annu. Rpt. Michigan State Hort. Soc. 115:181-185.

Davies, F.S. 1984. Plant growth regulators in Florida citrus production. The Citrus Ind. 65:26-31.

Forshey, C.G. 1986. Chemical fruit thinning of apple. Cornell Coop. Ext. Bul. 116.

Goffinet, M.C., T.L. Robinson, and A.N. Lakso. 1995. A comparison of 'Empire' apple fruit size and anatomy in unthinned and hand-thinned trees. J. Hort. Sci. 70:375-387.

Monselise, S.P. and E.E. Goldschmidt. 1982. Alternate bearing in fruit trees. Hort. Rev. 4:128-173.

Muraro, R.P. and J.W. Hebb. 1996. Budgeting costs and returns for Indian River citrus production, 1995-96. Economic information report, Univ. of Fla., Gainesville. Sept. 1996.

Pennsylvania State University. 1998. Pennsylvania tree fruit production guide-1998-1999. Univ. Park, Pa.

Silsby, K.J., T. Robinson, and F. Dellamano. 1991. Empire hand thinning study. Proc. New York State Hort. Soc. 136:175-185.

Southwick, S.M., K.G. Weis, J.T. Yaeger, and H. Zhou. 1995. Controlling cropping in 'Loadel' cling peach using gibberellin: Effects on flower density, fruit distribution, fruit firmness, fruit thinning, and yield. J. Amer. Soc. Hort. Sci. 120:1087-1095.

Stover, E., C. Telgheder, and T. Paine. 1995. Effect of NAA and Accel on thinning of 'Bartlett'. Proc. N.Y. State Hort. Soc. 140:50-51.

Wheaton, T.A. 1997. Alternate bearing of citrus in Florida, p. 87-92. In: S.H. Futch and W.J. Kender (eds.). Citrus flowering and fruiting short course. Univ. of Fla., Lake Alfred.

Wheaton, T.A. and I. Stewart. 1973. Fruit thinning of tangerines with napthaleneacetic acid. Proc. Fla. State Hort. Soc. 86:48-52.

Wilcox, W.F., A.M. Agnello, J. Kovach, and W.C. Stiles. 1995. Pest management recommendations for commercial tree-fruit production. Cornell Coop. Ext., Ithaca, N.Y.

Williams, M.W. and L.J. Edgerton. 1981. Fruit thinning of apples and pears with chemicals. U.S. Dept. Agr. Info. Bul. 289. 